\title{
Home Environment, Parenting and Counselling Of Adolescents on Healthy Living
}

\author{
Dr. (Mrs.) F. N. Modo \\ Department of Educational Foundations, Guidance and Counselling, University of Uyo, Uyo, Nigeria.
}

\begin{abstract}
The paper addresses the developmental issues of the adolescents' especially within the home environment. This environment is regarded as the familiar terrain of the adolescent. Parents are expected to guide these adolescents properly. They should more importantly be exposed to guidance counsellors as they face the storms of life. The author listed the areas where these adolescents need guidance and counselling. They include personal hygiene, exercise, peer association, drug and alcohol use. The paper argues strongly that the adolescents need to be exposed positively to good and healthy living if they are to become good and useful adults in future. It made some far reaching recommendations including the fact that every area of adolescents' development should be discussed with them early enough to avoid any pitfall.
\end{abstract}

Keywords: Home environment, parenting, counselling, healthy living , adolescents

\section{Introduction}

All human beings are reared in an environment which could be rural or urban in nature. The home environment is where an individual lives with all the physical, emotional, psychological, economic, social, educational and social conditions that affect the person throughout life. It is therefore important to note that the home environment of every individual accounts for the achievements and failures he encounters in the process of moving from one developmental stage of life to another especially as he gets to the adolescent stage of development. In life there are different stages of human development. Papalia and Olds (1989) see them as; (a) conception through birth (b) infancy, childhood, adolescence, adulthood and end of life. These stages of development have direct contact with the home environment which does influence them positively or negatively.

Denga (1988) defines the word environment as an aspect of the field in which an individual functions which includes the home, the school, the peer group, the classroom tone, the totality of a child's upbringing including the provision of his tissue needs, spiritual needs, psychological needs as well as social needs. He goes further to explain the fact that the home environment has effect on a person starting from the time he/she is conceived. Mothers' health, diet, emotional state and age make up the environment of the unborn child. Denga (1988) further explains that a child at birth moves from a "stable, beneficent but dull environment of the womb to an unstable, potentially hostile but stimulating environment outside the womb.

In the home a lot of things are put in place by parents and significant others to help moderate the activities of members of a home. In line with this article one of such is parenting. Parenting is used by Baumrind (1991) as a construct to capture normal variations in parents' efforts to control and also socialize their wards. In every home, parents employ different styles in bringing up their wards. Such styles include permissive, negligent, authoritarian and democratic (Melgosa, 2001). These styles employed by parents contribute to the decisions taken by members that make up a home especially the adolescents, the centre of this write up mostly as it concerns their health and health practises.

\section{Who is an adolescent?}

Adolescent is an individual that stands at the middle between childhood and adulthood stages of development. It is between the ages of $12-19$ years. Adolescence according to Myers (1995) is a period that extends from the beginning of sexual adult status. Consequently, Gary (2007) sees adolescence as a period of growth to maturity which begins at puberty and extends to the late teens or early twenties when the person is able to manage his own life. He goes further to explain that it is a period of physical, sexual, emotional, intellectual and social changes when the individual goes away from dependence on parents and protective confinement of the family and moves towards elative independence and social productivity within this stage of development. The adolescence period is characterized by different features which include physical, social, emotional and cognitive. At this stage, the adolescent has some tasks to achieve known as adolescent developmental tasks postulated by Harvighurst (1952) as follows:

- Adolescent's ability to accept his physique and properly adjusted to his sex role

- Ability to maintain cordial relationship with the opposite sex 
- Ability to develop his personality

- Ability to choose and maintain a vocational career

- Ability to achieve emotional and psychological freedom from parents, peers and significant others

- Ability to desire and achieve socially acceptable behaviour

- Ability to prepare for marriage and family life, among others.

\section{What Counselling Entails}

Counselling is a process of helping an individual to adjust properly to any given environment. This is very important because as the individual realizes himself and his immediate home environment which may be conducive or not conducive, the counselling activities could help him to make decisions for personal adaptation to the environment for maximum benefit. Onyekuru and Ekechukwu (2009) define counselling as a process of helping clients gain self-knowledge, self-awareness, self-direction, self-determination, self-dependent, selfdevelopment and self-actualization that will help him to achieve living, knowledge acquisition and problem solving skills. In order to achieve the aims and objectives of counselling, the work of counselling should be carried out by professionally empowered individual known as counsellors. A counsellor according to Modo and Ineja (2010) is one that is academically trained and holds an educational qualification of at least a first degree from any recognized University world wide. This individual is professionally trained in the field of counselling to help clients who may be in need of such help.

In counselling, so many services are rendered by the counsellors to both the adolescents and the entire people within the environment. The services are orientation, referral, placement, information, counselling educational, vocational, follow-up and research (Nwachuku, 2009 and Okobiah\&Okorodudu, 2004). The counsellor achieves the provision of these services to the clients through proper utilization of some professional skills which are regarded as counselling techniques. The skills are listening, establishment of rapport, restatement, confidentiality, empathy, case conferences, establishment of counselling clubs and homework (Modo \&Ineja, 2010).

\section{Counselling Adolescents on Healthy Living}

In counselling, all areas of human life are addressed such as educational, vocational and personal-social issues. In this article the author will be addressing personal issues as they affect adolescents for healthy living. It is true that at the adolescent stage of life one will conclude that he is healthy but so many things happen at this stage to the extent that some people die of preventable and treatable diseases. Worthy of note is the fact that developmental stages precede adulthood hence some habits at this stage could lead to some serious illnesses in adulthood. It is therefore very necessary that the adolescents be given sense of direction by the counsellor on the following issues for healthy living. They include but are not limited to: personal hygiene, nutrition, exercise, relaxation, rest and sleep, good behaviour, peer associations, sex education, drug and alcohol use. The aforementioned factors listed for counselling to achieve healthy living are discussed as follows:

Personal Hygiene: It is a process of keeping oneself and the things within one's environment clean so as to prevent sickness and disease. Ekong (2011) opined that improved standard hygiene, controls infections, enhances self confidence and relationships and promotes social health of the persons within the environment. The adolescents (with regard to personal hygiene), need counselling on how to keep the nails tidy, care of the hair, bathing, putting on and maintaining clean clothes, brushing of teeth atleast twice daily (Ekong 2011; Abia 2006). These areas are very vital to the growing adolescents in order to grow and sustain healthy adult life.

Nutrition: The term nutrition is defined by Ebong (2009) as the process of obtaining essential nutrients that are being used to make other substances that a person's body needs. It is a known fact that these nutrients are derived from the foods the person eats. Therefore good nutrition according to Ebong (2009:122) means "eating the right foods in the right proportion and at the right time". With all these at the background it becomes necessary that the today's adolescent needs to know more about balanced diet through counselling, since they are exposed to many types of junks foods due to the establishment of many fast food centres within the environment. Balanced diet therefore is known as diet that has all the essential nutrients in adequate proportion which help to maintain good health.

Exercise: This is another area that the adolescent needs counselling for healthy living. Exercise for the growing adolescent is highly recommended and when this recommendation comes from a professional counselling it shall be handled with all seriousness. The adolescent needs to know that by exercising his/her body every day through physical activities such as walking, jogging, swimming, running, playing football, tennis, basket ball and other sporting events, he/she can remain healthy and strong enough for the next stage of development.

Relaxation, rest and sleep: These three concepts are interrelated since they all point to the individual having a break. It is expected that the adolescents be reminded about the place of relaxation, rest and sleep in their lives. This has become very necessary because of the adolescent's access to cell phone and the internet. 
Most of them hardly sleep. They need to be encouraged to sleep after a whole day's activity which could be academic, physical or social.

Peer Associations: Peer group influence on adolescent healthy living cannot be over emphasized. Since peers are people of relatively the same age with the same attractiveness as in social, academic and physical activities, it is important to note that counselling has a lot to do in order to help peers imbibe and instill good character. In peer associations, there are the bad and the good sides. Good peer association encourages hard work, good neighbourness respect for constituted authority and obeying parents. To the bad peer association, most of the existing social vices are manipulated and encouraged. To them, bad habits like stealing, smoking, raping, drinking etc., are very common and they do not see anything wrong with these activities. This is where counselling comes in because they need to be helped early enough to understand and realize that good peer associations are good for healthy living.

Good Behaviour: Good behaviour is a contributory factor for adolescent healthy living. This is because when a growing individual who is under parental care behaves well, he avoids most problems associated with misbehavior. In this case they need counselling on respect for parents, elders, constituted authority, and maintenance of law and order within the environment where they live.

Drug and Alcohol Use: The adolescent needs to know about the consequences of drug and alcohol use early in life. They also need to be aware that most of the later life illnesses are associated with indulgence on drug and alcohol as a life style. Drug according to Anyanwu (2010) is any substance taken as medicine to cure illness. Ray and Ksir (2004) see drug as any substance, be it natural or artificial other than food with its chemical disposition, alters structure or functioning in the living organism. Alcohol is a substance in drinks such as wine and bear that can make one drunk. It is very important that the adolescent be exposed early in life to the dangers of abuse of these substances.

Sex Education: For the adolescents to enjoy healthy living at their developmental stage and the stage ahead, sex education is very vital. Sex education is a process of helping the adolescent develop positive attitude toward sex. It also exposes him to the consequences of early sexual intercourse and the associated risks as in an unplanned pregnancies, abortion and sexually transmitted infections (STIs). During talk on sex education, the counsellor has the duty of helping the adolescent understand that misuse of one's sex organ can lead to unhealthy life style and consequently death. The counsellor should also be able to provide the adolescent all necessary information regarding premarital sex and provide counselling that will help to prepare him/her for marriage. It is the duty of the counsellor to ensure that adolescents are made to know these areas of need and be acquainted with what to encounter in their life's journey.

\section{Conclusion}

It is worthy of note that home environment, parenting and counselling of the adolescent on healthy living is a topic that requires urgent attention in order to help the adolescents properly fit into the environment and also maintain progressive adult life. It is therefore opening more opportunities for the counsellors within the immediate environment to affect their society for positive and progressive adolescent healthy living.

Counsellors should endeavour to address all areas of the life of the adolescentsviz educational, personal-social and vocational within the located environment for it is only then that their services to humanity will be useful and the recipients will see themselves as living healthily.

\section{Recommendations}

As part of contributions to knowledge the author recommends as follows:

1. Adolescents should be helped to understand their environment properly and be able to manage the environmental challenges to their own benefits.

2. Parents should be made to understand that adolescence has its own stress and so they should not add to the existing stress which comes in various forms; social, psychological, or emotional.

3. Professional counsellors within the environment should please begin to practice so as to provide opportunity for both parents and adolescents to benefit from their professional training.

4. All areas of adolescents development should be discussed with them early enough to avoid pitfalls and for successful transition to adulthood.

\section{References}

[1] Abia, S. (2006).Growing-up responsibly. Uyo: Robertminder international.

[2] Anyanwu, J. I. (2010). Alcohol and drug counselling. In M. A. Obidoa and I. C. S. Ifelunni (eds) Counselling youths in contemporary Nigeria. NsukkaChuka Educational Publishers.Pp.141-162.

[3] Baumrind, D. (1991). The influence of parenting style on adolescent competence and substance use.Journal of early adolescence. 11(1), 56-95.

[4] Denga, D. I. (1988). Educational and social psychology. Calabar: Rapid education publishers.

[5] Ebong, R. D. (2009). Community health \& issues. Abak: Riduma printers and publishers.

[6] Ekong, I. E. (2011).Grooming the girl child. Uyo: GT technologies. 
[7] Gary, R. C. (2007). Christian counselling(3rd ed.) Illinois: Tyndale house Publishers.

[8] Harvighurst, R. (1952). Human development and education. New York: Longmans Green.

[9] Melgosa, J. (2001). To adolescents and parents. Spain: Editorial safeliz.

[10] Modo, F. N. and Ineja, A. E. (2010).Rebranding skills for counsellors toward curbing personal social problems in the school system.Ibom Journal of Counselling(1) 1, pp.40-46.

[11] Myers, D. G. (1995).Psychology (4th ed). New York: Worth publishers.

[12] Nwachuku, D. N. (2009).Guidance and counselling practicum (2nd ed.). Calabar: University of Calabar Press.

[13] Okobiah, O. C. and Okorodudu (2004).Guidance and counselling(2nd ed.) Benin City: Ethiope publishers.

[14] Onyekuru, B. and Ekechukwu, R. (2009).New dawn in counselling psychology in school and non-school settings.Port Harcourt: University of Port Harcourt Press.

[15] Papalia, D. E. and Olds, S. W. (1989).Human development. New York: McGraw-Hill Book.

[16] Ray, O. and Ksir, C. (2004).Drugs, society and human behaviour. Boston: McGraw Hill. 